\title{
Sistem Penunjang Keputusan Seleksi Karyawan Terbaik PT. Golden Living Indonesia Dengan Metode Wieghted Product
}

\author{
Maruloh$^{1}$, Muhammad Darussalam², Mochamad Nandi Susila ${ }^{3}$, Wahyudin ${ }^{4}$ \\ ${ }^{1}$ Sekolah Tinggi Manajemen Informatika dan Komputer Nusa Mandiri \\ 1e-mail: maruloh.mru@nusamandiri.ac.id \\ ${ }^{2,3,4}$ Universitas Bina Sarana Informatika \\ 2e-mail: muhammad.mds@bsi.ac.id \\ 3e-mail: mochamad.mnl@bsi.ac.id \\ 3e-mail: wahyudin.whd@bsi.ac.id

\begin{tabular}{ccc}
\hline Diterima & Direvisi & Disetujui \\
$01-11-2019$ & $02-01-2020$ & $06-01-2020$ \\
\hline
\end{tabular}

\begin{abstract}
Abstrak - Adanya pemilihan karyawan terbaik berdampak positif bagi perusahaan. Karena karyawan akan saling bersaing untuk menjadi yang terbaik. Persaingan ini akan meningkatkan produktivitas dalam bekerja. Ketika produktivitas seorang karwayan meningkat, perusahaan akan menjadi pihak yang paling diuntungkan karna juga akan meningkatkan mutu dari perusahaan tersebut. Permasalahan yang muncul dalam proses seleksi karyawan terbaik adalah kemampuan Sumber Daya Manusia yang terbatas dalam menentukan karyawan terbaik, dikarenakan banyaknya kriteria dan alternatif yang harus dimiliki oleh karyawan, sehingga menghambat proses penentuan karyawan terbaik. Untuk membantu dan mempercepat perusahaan dalam menentukan karyawan terbaik, dibutuhkan sebuah sistem penunjang keputusan untuk menentukan karyawan terbaik pada PT. Golden Living Indonesia menggunakan metode Weighted product (WP). Penggunaan metode dalam membangun Sistem Pununjang Keputusan (SPK) sangat penting untuk mempermudah proses dan meminimalisirkan kesalahan karna berlandaskan pada metode yang telah menjadi acuan. Pada metode Weighted Product (WP), ditentukan kriteria dalam penentuan karyawan terbaik, yaitu Kehadiran, Perilaku, Kerjasama, Ketelitian, dan Inisiatif Kerja. Dari hasil perhitungan nilai-nilai yang diolah dengan menggunakan metode Wieghted Product (WP) didapatkan hasil karyawan terbaik atas nama Ari dengan nilai akhir V=0,1045.
\end{abstract}

Kata Kunci: Sistem Penunjang Keputusan, karyawan terbaik, Weighted Product

\begin{abstract}
The selection of the best employees has a positive impact on the company. Because employees will compete with each other to be the best. This competition will increase productivity at work. When the productivity of a employee increases, the company will be the most profitable because it will also improve the quality of the company. The problem that arises in the best employee selection process is the ability of Human Resources is limited in determining the best employees, due to the many criteria and alternatives that must be owned by employees, thus hampering the process of determining the best employees. To help and speed up the company in determining the best employees, a decision support system is needed to determine the best employees at PT. Golden Living Indonesia uses the Weighted product (WP) method. The use of methods in building Decision Support Systems (SPK) is very important to simplify the process and minimize errors because it is based on methods that have become a reference. In the Weighted Product (WP) method, criteria are determined in determining the best employees, namely Attendance, Behavior, Cooperation, Accuracy, and Work Initiatives. From the calculation of the values processed using the Wieghted Product (WP) method, the best employee results obtained on behalf of Ari with a final value of $V=0.1045$.
\end{abstract}

Keywords: Decision Support System, the best employee, Weighted Product

\section{PENDAHULUAN}

Persaingan kerja antar karyawan merupakan suatu hal positif yang dapat meningkatkan produktivitas dalam berkerja. Ketika produktivitas seorang karwayan meningkat, perusahaan akan menjadi pihak yang paling diuntungkan karna juga akan meningkatkan mutu dari perusahaan tersebut. Sehingga untuk mencapai hal tersebut, PT. Golden Living Indonesia mengadakan pemberian penghargaan kepada karwayan terbaik guna memotivasi para karyawannya untuk berkerja lebih 
baik. Pemberian penghargaan tidak sekedar untuk meningkatkan produktivitas karyawan dalam melaksanakan perkerjaannya tetapi juga untuk meningkatkan keharmonisan antara karyawan dan perusahaan. Untuk membantu dan mempercepat perusahaan dalam menentukan karyawan terbaik, dibutuhkan sebuah sistem penunjang keputusan untuk menentukan karyawan terbaik pada PT. Golden Living Indonesia menggunakan metode Weighted product (WP).

Sistem Pendukung Keputusan dapat diartikan sebagai suatu sistem yang dirancang yang digunakan untuk mendukung manajemen didalam mengambil keputusan (Latif, Jamil, \& Abbas, 2018). Sedangkan Metode Weighted Product (WP) Merupakan sebuah metode di dalam menentukan suatu keputusan dengan cara perkalian untuk menghubungkan antar atribut berdasarkan rating setiap atribut dipangkatkan dulu dengan bobot atribut yang bersangkutan (Nofriansyah, 2015).

Permasalahan yang akan muncul ketika akan menentukan karyawan terbaik adalah kemampuan terbatas yang dimiliki oleh Sumber Daya Manusia (SDM) yang dalam hal ini merupakan pengambil keputusan pada perusahaan untuk menentukan karyawan terbaik, dikarenakan bergitu banyaknya kriteria dan alternatif untuk diperhitungkan seringkali menghambat proses penentuan karyawan terbaik.

Berdasarkan masalah yang telah dipaparkan sebelumnya, maka dibuat Sistem Penunjang Keputusan (SPK) untuk mempermudah dan mempersingkat waktu dalam proses untuk menentukan karyawan terbaik. Penggunaan metode dalam membangun Sistem Pununjang Keputusan (SPK) sangat penting untuk mempermudah proses dan meminimalisirkan kesalahan karna berlandaskan pada metode yang telah menjadi acuan. Komputer akan berperan sebagai media untuk memberikan informasi yang dibutuhkan oleh Sumber Daya Manusia (SDM) sedangkan metode merupakan acuan yang digunakan untuk menyelesaikan suatu masalah.

Penelitian sebelumnya yang pernah dilakukan dengan metode Weighted product (WP) diantaranya dilakukan oleh (Arsyad, 2016). Untuk Seleksi Calon Ketua Badan Eksekutif Mahasiswa (BEM) STMIK Banjarbaru. Dalam penelitian tersebut dalam memecahkan masalah, penelitian ini menggunakan metode Weighted Product (WP) untuk seleksi calon ketua BEM STMIK Banjarbaru untuk membantu proses pengambilan keputusan. Kriteria yang digunakan untuk seleksi adalah Frekuensi Mengikuti LDK (Latihan Dasar Kepemimpinan), Prestasi (IPK), Visi dan Misi, Prestasi Non Akademik dan Dukungan Awal. Dengan hasil, Sistem Pendukung Keputusan Untuk Seleksi Calon Ketua Badan Eksekutif Mahasiswa (BEM) STMIK Banjarbaru dapat membantu dalam melakukan penilaian sesuai dengan kriteria yang sudah ditentukan.
Dalam penelitian lain yang dilakukan oleh (Susliansyah, Aria, \& Susilowati, 2019) dalam hal pemilihan laptop terbaik, Pembobotan metode Weighted Product dihitung berdasarkan tingkat kepentingan. Sistem ini membutuhkan masukan nilai bobot berdasarkan kebutuhan calon pembeli berupa harga, kapasistas RAM, jenis prosesor, kapasitas Harddisk, dan VGA (Video Grapphics Array). Hasil dari pennelitian ini memberikan saran laptop sesuai dengan kebutuhan spesifikasi untuk calon pembeli dengan tingkat akurasi perhitungan $100 \%$ berdasarkan perhitungan manual dan perhitungan pada sistem pendukung keputusan pemilihan laptop. Penelitian lain dengan menggunakan metode Weighted Product juga pernah dilakukan oleh (Yusnaeni, 2018) untuk menentukan pemilihan siswa terbaik pada SMAN 14 Bekasi. Dalam penelitian disimpulkan bahwa diperlukan metode pendukung keputusan yang akan membantu pengolahan data dari segi kriteria yang multikritaria bukan hanya berdasarkan nilai saja. Metode WP merupakan salah satu metode yang digunakan sebagai sistem pendukung keputusan untuk membantu menyelesaikan permsalahan dengan sistem pendukung keputusan dengan multikriteria.

\section{METODOLOGI PENELITIAN}

Kerangka pemikiran dalam penelitian ini ditunjukan pada gambar berikut:

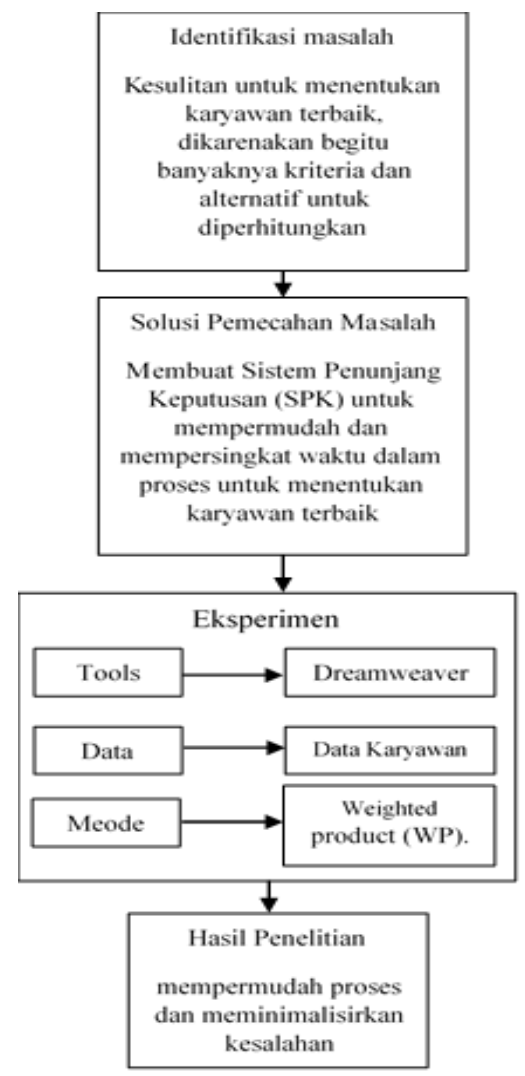

Sumber : hasil penelitian (2019)

Gambar 1. Kerangka Pemikiran 
Dalam merancang logic database, penulis menggunakan Entity Relationship Diagram (ERD) dan Logical Record Structure (LRS). ERD digunakan Untuk pemodelan basis data relasional. ERD tidak digunakan untuk penyimpanan basis data yang menggunakan OODBMS (Object Oriented Database management System). ERD merupakan suatu model atau teknik pendekatan yang dapat menyatakan suatu gambaran hubungan entity didalam sebuah sistem, dimana hubungan tersebut dinyatakan sebagai one-to-one, one-to- many, manyto-one dan many-to-many LRS merupakan hasil dari pemodelan Entity Relational Ship (ER) beserta atributnya sehingga bisa terlihat hubunganhubungan antar entitas.

Teknik pengumpulan data pada penelitian ini adalah sebagai berikut:

1. Data Primer

Data yang diperoleh dari perusahaan seperti data karyawan

2. Data Sekunder

Data yang diperoleh dari hasil observasi dan studi pustaka yang dilakukan pada penelitian terdahulu.

Metode Weighted Product (WP) merupakan salah satu metode Multi Attribute Decision Making (MDAM) yang dapat melakukan perhitungan atas beberapa kriteria. Seperti metode lainnya, Weighted Product (WP) juga perlu melalui tahap normalisasi. Konsep dasar normalisasi dari metode Weighted Product (WP) adalah mencari Si dengan melakukan pemangkatan nilai dari kriteria pada suatu alternatif dengan nilai bobot yang dimiliki setiap kriteria. Setelah itu nilai $\mathrm{Si}$ ᄀakan digunakan untuk mencari nilai $\mathrm{Vi}$ dengan cara membagi nilai $\mathrm{Si}$ dengan $\sum \mathrm{Si}$, sehingga akan menghasilkan nilai untuk setiap alternatif

Secara rinci langkah-langkah dalam perhitungan Weighted Product adalah sebagai berikut:

1. Menentukan kriteria pemilihan $\{\mathrm{C} 1, \mathrm{C} 2 \ldots \mathrm{Cn})$

2. Penilaian bobot kepentingan tiap kriteria

3. Penilaian tiap alternatife menggunakan semua atribut

4. Dari data penilaian tiap bobot atribut dan nilai alternatif dibuatmatrik keputusan (X)

5. Dilakukan proses perbaikan / normalisasi bobot kriteria (W)

$w_{j}=\frac{w_{j}}{\Sigma w_{j}}$.

Keterangan :

$\mathrm{W}_{\mathrm{j}} \quad=$ Bobot atribut

Z $W_{i}=$ Penjumlahan bobot atribut

6. Dilakukan proses normalisasi (S) matrik keputusan dengan cara mengalikan rating atribut, dimana rating atribut terlebih dahulu harus dipangkat kandengan bobot atribut.

Atribut Keuntungan: pangkat bernilai positif

Atribut Biaya : pangkat bernilai negative

$S_{i}=\Pi_{j}^{n}=1 X_{i j} W_{j}$.

$\mathrm{Si}=$ Hasil normalisasi matrik.

$\mathrm{Xij}=$ Nilai variabel dari alternatif pada setiap atribut.

$\mathrm{Wj}=$ Nilai bobot kriteria.

$\mathrm{n}=$ Banyaknya kriteria.

$\mathrm{i}=$ Nilai alternatif.

$\mathrm{j}=$ Nilai kriteria.

7. Preferensi relatif dari setiap alternatif

$V_{i}=\frac{\Pi_{j}^{n}=1 x_{i j} w_{j}}{\Pi_{j}^{n}=1\left(x_{j^{*}}\right) w_{j}}$.

$\mathrm{Vi}=$ Hasil preferensi alternatif ke-i.

$\mathrm{X} i \mathrm{j}=$ Nilai variabel dari alternatif pada setiap atribut.

$\mathrm{Wj}=$ Nilai bobot kriteria.

$\mathrm{n}=$ Banyaknya kriteria

$\mathrm{i}=$ Nilai alternatif.

$\mathrm{j}=$ Nilai kriteria.

* = Banyaknya kriteria yang telah dinilai pada vektor $\mathrm{S}$

Dalam penyelesaian pemilihan karyawan terbaik dengan menggunakan metode Weighted Product diperlukan kriteria-kriteria dan bobot untuk melakukan perhitungan sehingga akan didapat alternatif terbaik. Kriteria-kriteria yang dibutuhkan antara lain Kehadiran, Perilaku, Kerjasama, Ketelitian, dan Inisiatif Kerja. Seluruh kriteria tersebut yang digunakan pada PT.Golden Living Indonesia dan bersifat banefit. Secara rinci kriteria yang digunakan adalah sebagai berikut:

Tabel 1. Kriteria

\begin{tabular}{|c|c|}
\hline Kriteria & Keterangan \\
\hline C1 & Kehadiran \\
\hline C2 & Perilaku \\
\hline C3 & Kerjasama \\
\hline C4 & Ketelitian \\
\hline C5 & Loyalitas \\
\hline
\end{tabular}

Sumber : hasil penelitian (2019)

Tabel 2. Keterangan Bobot

\begin{tabular}{|c|c|}
\hline Keterangan Jenis Bobot & Bobot \\
\hline Sangat Tinggi & 5 \\
\hline Tinggi & 4 \\
\hline Sedang & 3 \\
\hline Rendah & 2 \\
\hline Sangat Rendah & 1 \\
\hline
\end{tabular}

Masing-masing kriteria yang telah disebutkan memiliki sub kriteria, range niali sub kriteria,

Tabel 3. Range Nilai Sub Kriteria

\begin{tabular}{|c|c|}
\hline Keterangan Jenis Nilai & Range Nilai \\
\hline Sangat Tinggi & $81-100$ \\
\hline Tinggi & $61-80$ \\
\hline Sedang & $41-60$ \\
\hline Rendah & $21-40$ \\
\hline
\end{tabular}




\begin{tabular}{|c|c|}
\hline Sangat Rendah & $0-20$ \\
\hline Sumber : hasil penelitian (2019)
\end{tabular}

Tabel 4. Pembobotan Kriteria

\begin{tabular}{|c|c|c|}
\hline Kriteria & Bobot & Keterangan Jenis Pembobotan \\
\hline Kehadiran & 5 & Sangat Tinggi \\
\hline Perilaku & 4 & Tinggi \\
\hline Kerjasama & 3 & Sedang \\
\hline Ketelitian & 3 & Sedang \\
\hline Loyalitas & 3 & Sedang \\
\hline
\end{tabular}

Sumber : hasil penelitian (2019)

a. Kehadiran

Pada kriteria Kehadiran memiliki sub kriteria sebagai berikut :
1) Sangat Tinggi, memiliki range niali $=81$ - 100
2) Tinggi, memiliki range nilai $=61-80$
3) Sedang, memiliki range nilai $=41-60$
4) Rendah, memiliki range nilai $=21-40$
5) Sangat Rendah, memiliki range nilai $=0-20$

b. Perilaku

Pada kriteria Prilaku memiliki sub kriteria sebagai berikut :

1) Sangat Tinggi, memiliki range niali $=81-100$

2) Tinggi, memiliki range nilai $=61-80$

3) Sedang, memiliki range nilai $=41-60$

4) Rendah, memiliki range nilai $=21-40$

5) Sangat Rendah, memiliki range nilai $=0-20$

c. Kerjasama

Pada kriteria Kerjasama memiliki sub kriteria sebagai berikut :

1) Sangat Tinggi, memiliki range niali $=81-100$

2) Tinggi, memiliki range nilai $=61-80$

3) Sedang, memiliki range nilai $=41-60$

4) Rendah, memiliki range nilai $=21-40$

5) Sangat Rendah, memiliki range nilai $=0-20$

d. Ketelitian

Pada kriteria Ketelitian memiliki sub kriteria sebagai berikut :

1) Sangat Tinggi, memiliki range niali $=81-100$

2) Tinggi, memiliki range nilai $=61-80$

3) Sedang, memiliki range nilai $=41-60$

4) Rendah, memiliki range nilai $=21-40$

5) Sangat Rendah, memiliki range nilai $=0-20$

e. Loyalitas

Pada kriteria Inisiatif Kerja memiliki sub kriteria sebagai berikut :

1) Sangat Tinggi, memiliki range niali $=81-100$

2) Tinggi, memiliki range nilai $=61-80$

3) Sedang, memiliki range nilai $=41-60$

4) Rendah, memiliki range nilai $=21-40$

5) Sangat Rendah, memiliki range nilai $=0-20$

\section{HASIL DAN PEMBAHASAN}

Pada bahasan ini akan dijabarkan hasil dari analisa sistem penunjang keputusan dengan metode weighted product dan dilanjutkan dengan penerapan aplikasi berbasis web untuk mendukung kegiatan penunjang keputusan pada PT.Golden Living Indonesia

\section{Penentuan Rating}

Dibawah ini adalah penentun rating dengan range kriteria yang telah dijabarkan sebelumnya

Tabel 5. Penentuan Rating

\begin{tabular}{|c|c|c|c|c|c|}
\hline \multirow{2}{*}{ ALTERNATIF } & \multicolumn{5}{|c|}{ KRITERIA } \\
\cline { 2 - 6 } & C1 & C2 & C3 & C4 & C5 \\
\hline A1 & 95 & 75 & 70 & 80 & 65 \\
\hline A2 & 95 & 80 & 70 & 85 & 70 \\
\hline A3 & 90 & 70 & 70 & 80 & 70 \\
\hline A4 & 95 & 90 & 75 & 75 & 75 \\
\hline A5 & 100 & 80 & 65 & 80 & 70 \\
\hline A6 & 100 & 80 & 70 & 70 & 60 \\
\hline A7 & 90 & 85 & 80 & 75 & 65 \\
\hline A8 & 80 & 95 & 85 & 75 & 80 \\
\hline A9 & 100 & 90 & 65 & 70 & 65 \\
\hline A10 & 95 & 90 & 70 & 70 & 90 \\
\hline Sunyyyy & & & & & \\
\hline
\end{tabular}

Sumber : hasil penelitian (2019)
Keterangan :
Contoh Kriteria
$\mathrm{C} 1=$ Kehadiran
$\mathrm{C} 2=\mathrm{Pe}$ rulaku
C3 $=$ Kerjasama
$\mathrm{C} 4=$ Ketelitian
C4 = Loyalitas
Contoh Alternatif
A1 = Jatmiko
A2 = Okta Prima Anggista
A3 = Andi Dwi Ariyanto
A4 = Rio Fajar Anggoro
A5 = Ponco Hariyanto
A6 = Rahmat Sri Yulianto
$\mathrm{A} 7=$ Sudoto
A8 = Abdul Muin
A9 = Trinanto
A10 = Abdul Wahidun

\section{Perbaikan Nilai Bobot}

Tahapan selanjutnya yaitu perbaikan nilai bobot, dengan metode weighted product (WP) untuk mendapatkan nilai $\sum \mathrm{W}=1$, maka diperlukan rumus $\mathrm{Wi} /\left(\sum \mathrm{W}\right)$.

Sehingga akan didapat perhitungan masing- 
masing bobot kriteria

$$
\begin{aligned}
& \mathrm{W}_{\text {awal }}=5+4+3+3+3=18 \\
& \mathrm{~W} 1=\frac{5}{5+4+3+3+3}=0,2778 \\
& \mathrm{~W} 2=\frac{4}{5+4+3+3+3}=0,2222 \\
& \mathrm{~W} 3=\frac{3}{5+4+3+3+3}=0,1667 \\
& \mathrm{~W} 4=\frac{3}{5+4+3+3+3}=0,1667 \\
& \mathrm{~W} 5=\frac{3}{5+4+3+3+3}=0,1667
\end{aligned}
$$

Hasil penjumlahan bobot dari seluruh kriteria

$$
\begin{aligned}
& \left(\sum \mathrm{W}\right)=1, \\
& \quad \text { atau } \\
& 0,2778+0,2222+0,1667+0,1667+0,1667=1
\end{aligned}
$$

\section{Proses Normalisasi}

Setelah melakukan perbaikan nilai bobot, berikut adalah hasil dari proses normalisasi:

$\mathrm{S} 1=\left(95^{0,2778}\right) *\left(75^{0,2222}\right) *\left(70^{0,1667}\right) *\left(80^{0,16667}\right) *\left(65^{0,1667}\right)$ $=78,1782$

$\mathrm{S} 2=\left(95^{0,2778}\right) *\left(80^{0,2222}\right) *\left(70^{0,1667}\right) *\left(85^{0,16667}\right) *\left(70^{0,16667}\right)$ $=81,1088$

$\mathrm{S} 3=\left(90^{0,2778}\right) *\left(70^{0,2222}\right) *\left(70^{0,1667}\right) *\left(80^{0,16667}\right) *\left(70^{0,16667}\right)$ $=76,7839$

$\mathrm{S} 4=\left(95^{0,2778}\right) *\left(90^{0,2222}\right) *\left(75^{0,1667}\right) *\left(75^{0,16667}\right) *\left(75^{0,16667}\right)$ $=83,4377$

S5 $=\left(100^{0,2778}\right) *\left(80^{0,2222}\right) *\left(65^{0,1667}\right) *\left(80^{0,16667}\right) *\left(70^{0,16667}\right.$ )$=80,4456$

S6 $=\left(100^{0,2778}\right) *\left(80^{0,2222}\right) *\left(70^{0,1667}\right) *\left(70^{0,16667}\right) *\left(60^{0,16667}\right.$ )$=77,6319$

$\mathrm{S} 7=\left(90^{0,2778}\right) *\left(85^{0,2222}\right) *\left(80^{0,1667}\right) *\left(75^{0,16667}\right) *\left(65^{0,16667}\right)$ $=80,1006$

$\mathrm{S} 8=\left(80^{0,2778}\right) *\left(95^{0,2222}\right) *\left(85^{0,1667}\right) *\left(75^{0,16667}\right) *\left(80^{0,16667}\right)$ $=83,0961$

$\mathrm{S} 9=\left(100^{0,2778}\right) *\left(90^{0,2222}\right) *\left(65^{0,1667}\right) *\left(70^{0,16667}\right) *\left(65^{0,16667}\right.$ )$=79,7693$

$\mathrm{S} 10=\left(95^{0,2778}\right) *\left(90^{0,2222}\right) *\left(70^{0,1667}\right) *\left(70^{0,16667}\right) *\left(90^{0,16667}\right.$ ) $=84,0567$

Hasil dari akumulasi nilai normalisasi diperoleh sebagai berikut:
$80,4456+77,6319+80,1006+83,0961+79,7693+$ $84,0567=804,6088$

\section{Proses Peringkat}

Setelah tahapan normalisasi dilakukan, langkah terakhir dalam sistem penunjang keputusan seleksi karyawan dengan metode weighted product adalah dengan menggunakan $\mathrm{Si} /\left(\sum \mathrm{S}\right)$. Dibawah ini adalah hasil dari proses pemeringkatan:

$$
\begin{aligned}
& \mathrm{V} 1=\frac{7 \mathrm{~g}_{0}, 17 \mathrm{g2}}{\mathrm{804,6089}}=0,0972 \\
& \mathrm{~V} 2=\frac{91,1098}{804,6098}=0,1008 \\
& \mathrm{~V} 3=\frac{76_{a} 7939}{804,6098}=0,0954 \\
& \mathrm{~V} 4=\frac{\mathrm{ga}, 4 \mathrm{a77}}{\mathrm{g04,6089}}=0,1037 \\
& \mathrm{~V} 5=\frac{\mathrm{g0,}, 4456}{\mathrm{g04}, 60 \mathrm{gs}}=0,1000 \\
& \mathrm{~V} 6=\frac{77_{\star} 61919}{804,6089}=0,0965 \\
& \mathrm{V7}=\frac{\mathrm{80,1006}}{\mathrm{804,608 \textrm {g }}}=0,0996 \\
& \mathrm{~V} 8=\frac{92,0961}{804,6089}=0,1033 \\
& \mathrm{V9}=\frac{79,769 \mathrm{I}}{804,6089}=0,0991 \\
& \mathrm{~V} 10=\frac{\mathrm{g4}, 0567}{\mathrm{g04,6089}}=0,1045
\end{aligned}
$$

$$
\begin{array}{ll}
\text { V10 }=0,1045 & (1=\text { Abdul Wahidun }) \\
\text { V4 }=0,1037 & (2=\text { Rio Fajar Anggoro }) \\
\text { V8 }=0,1033 & (3=\text { Abdul Muin }) \\
\text { V2 }=0,1008 & (4=\text { Okta Prima Anggista }) \\
\text { V5 }=0,1000 & (5=\text { Ponco Hariyanto }) \\
\text { V7 }=0,0996 & (6=\text { Sudoto }) \\
\text { V9 }=0,0991 & (7=\text { Trinanto }) \\
\text { V1 }=0,0972 & (8=\text { Jatmiko }) \\
\text { V6 }=0,0965 & (9=\text { Rahmat Sri Yulianto }) \\
\text { V3 }=0,0954 & (10=\text { Andi Dwi Ariyanto })
\end{array}
$$

Dengan metode weighted product didapatkan hasil seleksi karyawan terbaik adalah Abdul Wahidun dengan nilai 0,1045.

\section{Rancangan Basis Data}

Kemudian peneliti melakukan rancangan basis data sebagai tempat penampungan data pengolahan sistem penunjang keputusan seleksi karyawan pada PT.Golden Living Indonesia. Berikut gambaran basis data dalam Entity Relationship Diagram dan Logical Record Structured:

$\Sigma \mathrm{S}=78,1782+81,1088+76,7839+83,4377+$ 


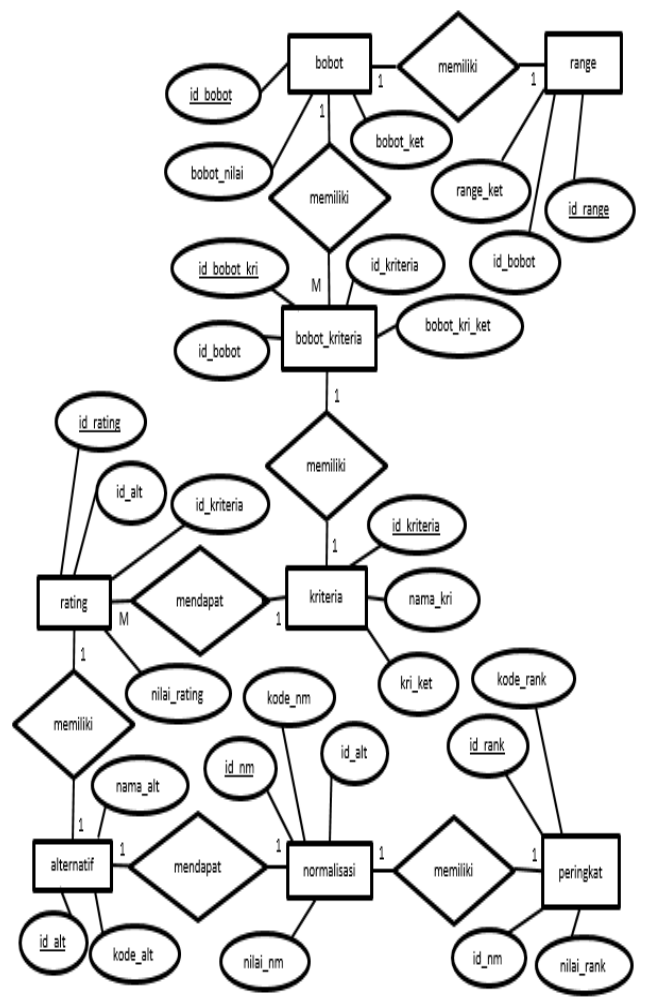

Sumber : hasil penelitian (2019)

Gambar 2. Entity Relationship Diagram

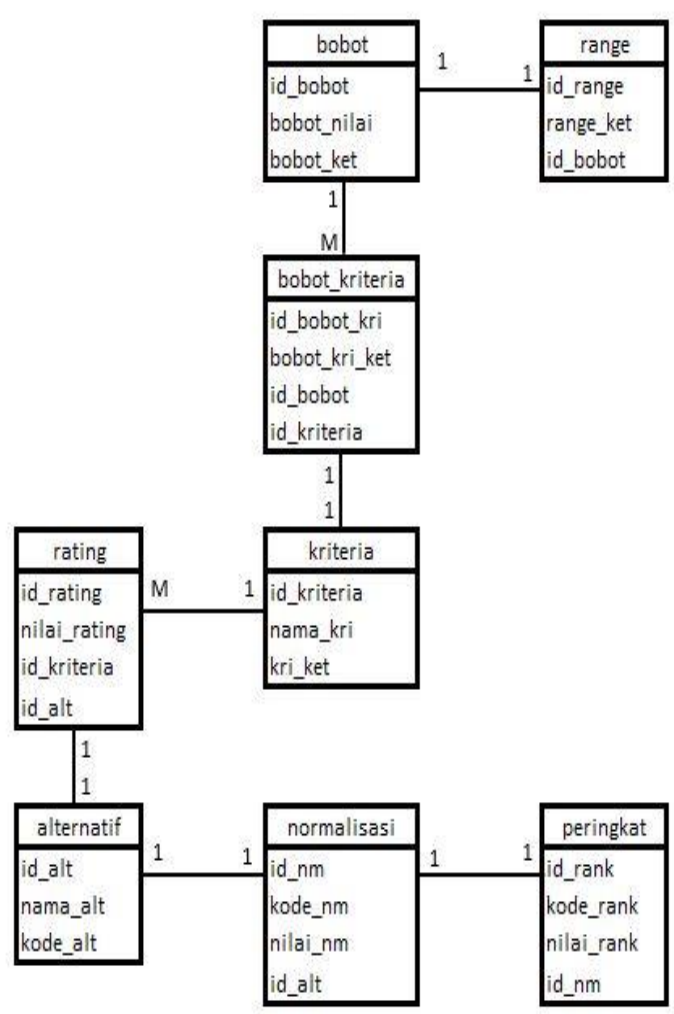

Sumber : hasil penelitian (2019)

Gambar 3. Logical Record Structured

\section{Implementasi Aplikasi Berbasis Web}

Dibawah ini merupakan tampilan implementasi aplikasi sistem penunjang keputusan seleksi karyawan terbaik pada PT.Golden Living Indonesia:
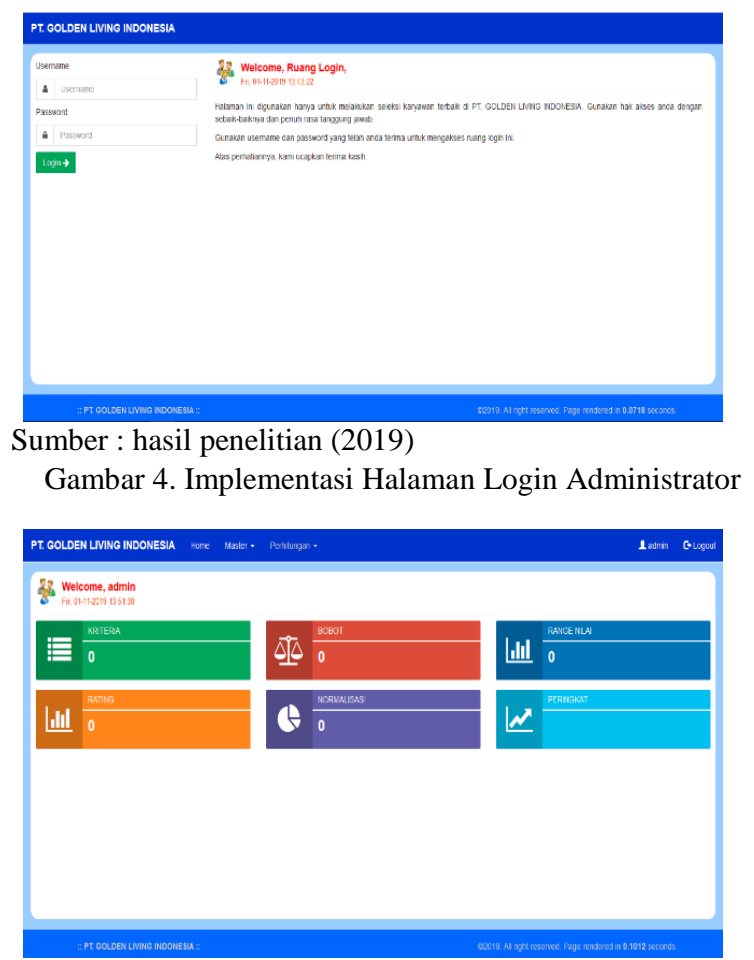

Sumber : hasil penelitian (2019)

Gambar 5. Implementasi Halaman Menu Utama

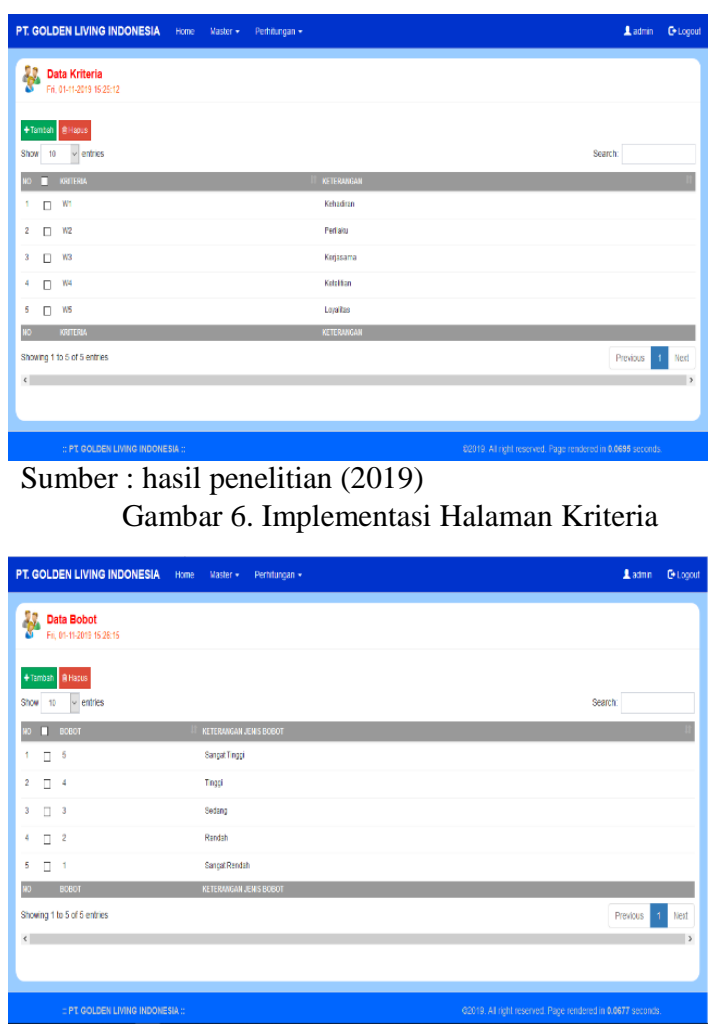

Sumber : hasil penelitian (2019)

Gambar 7. Implementasi Halaman Bobot

86 Sistem Penunjang Keputusan Seleksi Karyawan Terbaik PT. Golden Living Indonesia Dengan Metode Wieghted Product 


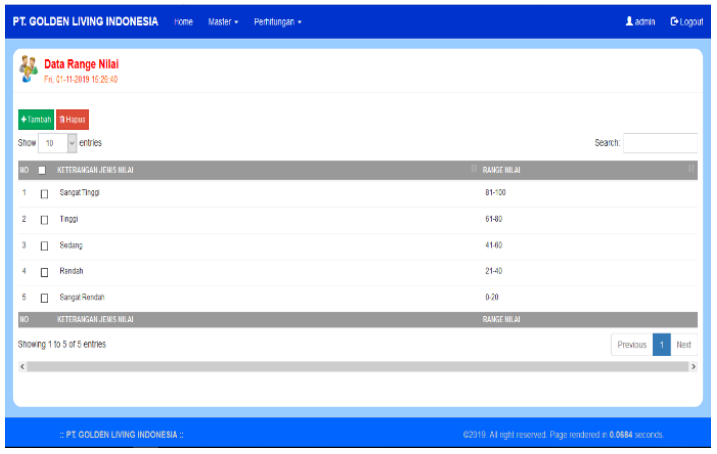

Sumber : hasil penelitian (2019)

Gambar 8. Implementasi Halaman Range Nilai

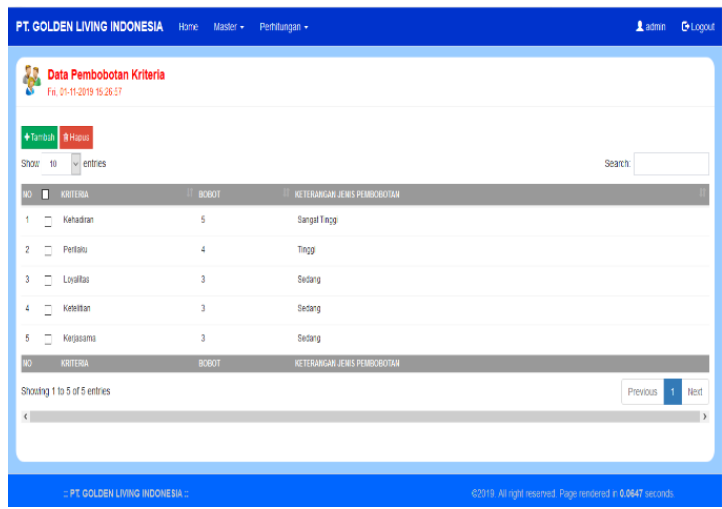

Sumber : hasil penelitian (2019)

Gambar 9. Implementasi Halaman Pembobotan Kriteria

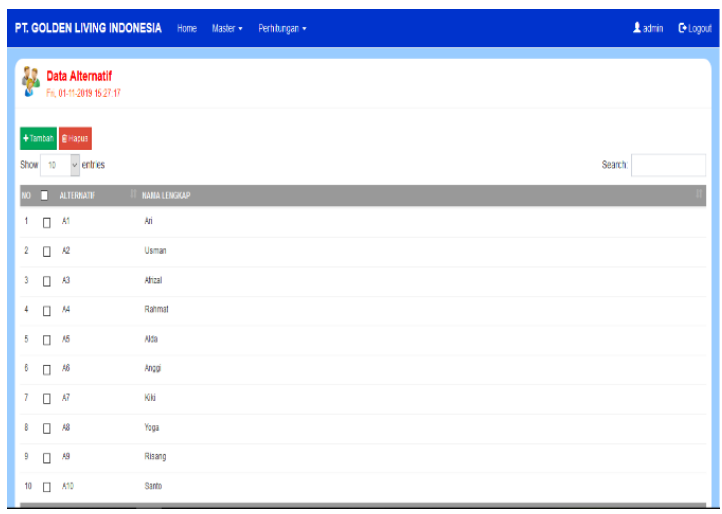

Sumber : hasil penelitian (2019)

Gambar 10. Implementasi Halaman Alternatif

\begin{tabular}{|c|c|c|}
\hline PT, GOLDEN LNWG & & \\
\hline \&8 Data Penentats & & \\
\hline 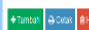 & & \\
\hline 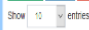 & & searn \\
\hline D I Alamir & $\min$ & 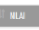 \\
\hline I kㅐ & m/chidite & 95 \\
\hline 2 口 & mal pratare & 75 \\
\hline 3 口 & Injonoum & n \\
\hline 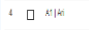 & mis icatlas & " \\
\hline 5 口 & "sis loaphas & 6 \\
\hline 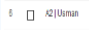 & 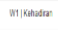 & " \\
\hline , 口 squmn & maipmatia & " \\
\hline 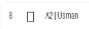 & 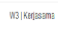 & $\pi$ \\
\hline 口 & mir vatats & is \\
\hline 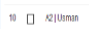 & 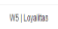 & $n$ \\
\hline
\end{tabular}

Sumber : hasil penelitian (2019)

Gambar 11. Implementasi Halaman Penentuan Rating

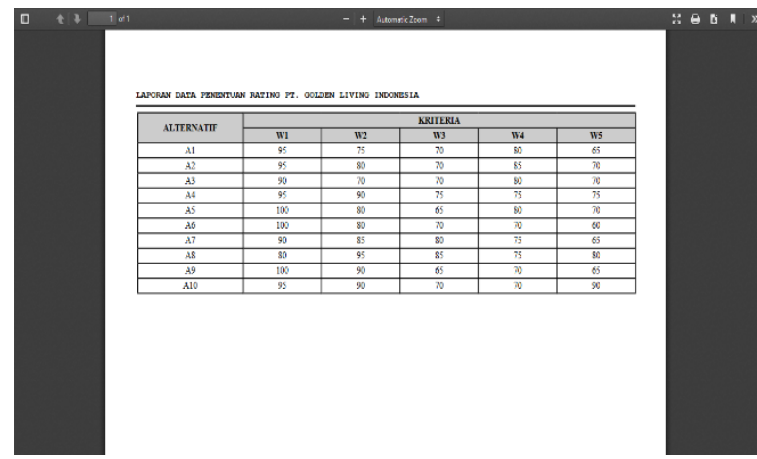

Sumber : hasil penelitian (2019)

Gambar 12. Implementasi Halaman Laporan Rating

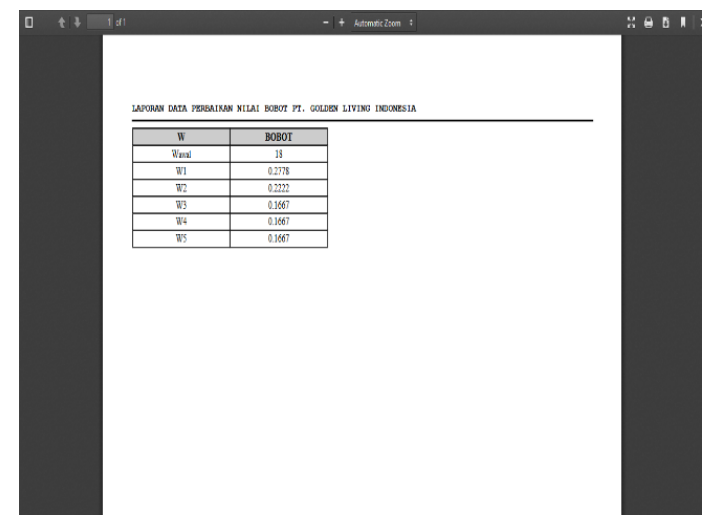

Sumber : hasil penelitian (2019)

Gambar 13. Implementasi Halaman Laporan Perbaikan Nilai Bobot

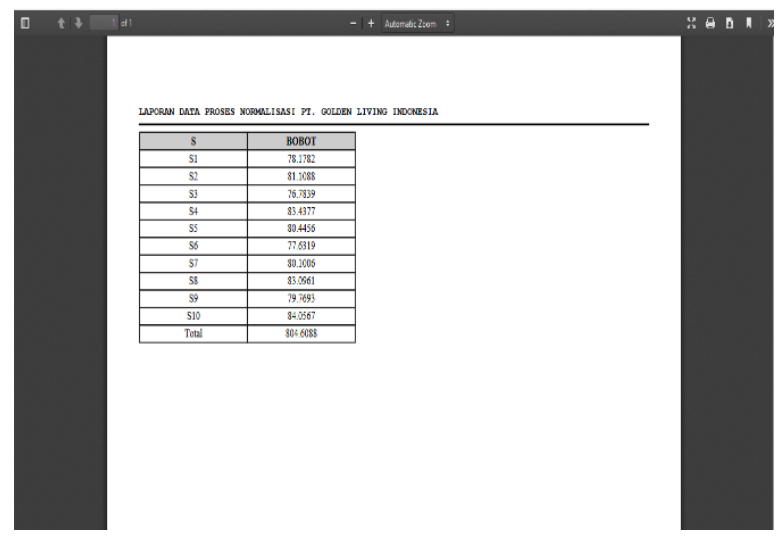

Sumber : hasil penelitian (2019)

Gambar 14. Implementasi Halaman Normalisasi

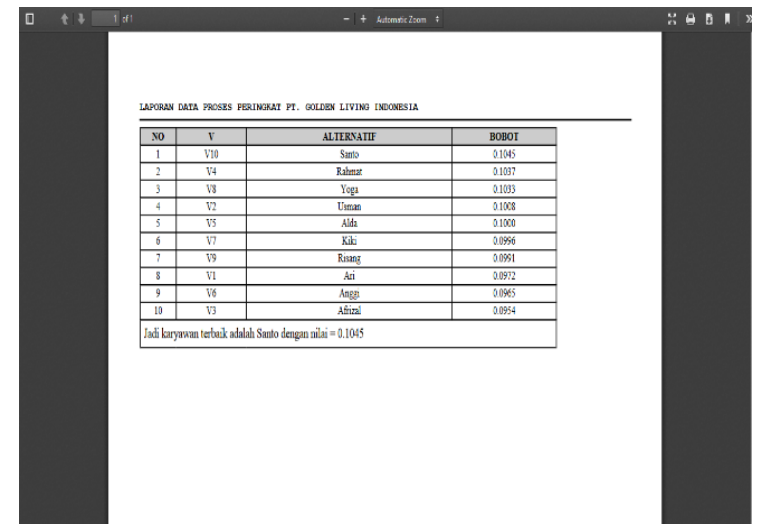

Sumber : hasil penelitian (2019)

Gambar 15. Implementasi Halaman Proses Peringkat 


\section{KESIMPULAN}

Berdasarkan penelitian yang telah dilakukan, maka peneliti mengambil beberapa kesimpulan diantaranya:

1. Sistem Pununjang Keputusan (SPK) sangat penting untuk mempermudah proses dan meminimalisirkan kesalahan karna berlandaskan pada metode yang telah menjadi acuan.

2. Kriteria-kriteria yang digunakan dalam penelitian ini, seperti, kehadiran, perilaku, kerjasama, ketelitian, dan inisiatif kerja sangat tepat digunakan dalam metode wieghted product sebagai acuan dalam sistem penunjang keputusan seleksi karyawan PT. Golden Living Indonesia

3. Diharapkan metode weighted product yang digunakan serta implementasi aplikasi sistem penunjang keputusan seleksi karyawan PT.Golden Living Indonesia dapat membantu dan mempercepat perusahaan dalam menentukan karyawan terbaik berdasarkan kriteria-kriteria yang ditentukan.

\section{REFERENSI}

Arsyad, M. (2016). Sistem Pendukung Keputusan Untuk Seleksi Calon Ketua Badan Eksekutif Mahasiswa ( BEM ) STMIK Banjarbaru Dengan Metode Weighted Product ( WP ) Muhammad Arsyad. Jurnal Bianglala Informatika, 4(1), 51-59.

Latif, L. A., Jamil, M., \& Abbas, S. H. (2018). Sistem Pendukung Keputusan Teori dan Implementasi.

Nofriansyah, D. (2015). Konsep Data Mining Sistem Pendukung Keputusan (I).

Susliansyah, S., Aria, R. R., \& Susilowati, S. (2019). Sistem Pemilihan Laptop Terbaik Dengan Menggunakan Metode Weighted Product (Wp). Jurnal Techno Nusa Mandiri, 16(1), $15-20$.

https://doi.org/10.33480/techno.v16i1.105

Yusnaeni, W. (2018). Pemilihan Siswa Terbaik Melalui Metode Pendukung Keputusan WP (Weighted Product). Indonesian Journal on Software Engineering, 4(2). 